CHAPTER ONE

\title{
INTRODUCTION
}

No historical method is in any sense an alternative to heavy labour in historical sources. None can serve as a substitute for creativity. ${ }^{1}$

Trade has been a prominent feature of Indonesian history. Trading opportunities lured the Dutch to the Eastern hemisphere. Upon arrival they encountered a bustling commercial world in which the Vereenigde Oostindische Compagnie (VOC) soon found its place aided by military strength and political pressure. According to the stereotype the VOC tried to monopolize economic activity and discourage private business initiative. The colonial government of the nineteenth century is said to have done the same.

This predominance of political over economic considerations is deceptive. Private initiative was part and parcel of the economic processes at play in the Indonesian archipelago. A perpetual flow of credit formed the basis of the complex import/export trade. Protecting one's investment was of great concern to those involved, and the acquisition of information and security was crucial. In other words, there was a continuing reciprocity between credit, relevant business information and security concerns.

\section{Research Outline}

This research describes and analyses the world of commercial enterprise in Java in the period 1800-1942. The importance of trade in the economic development of Indonesia is unmistakable. ${ }^{2}$ The general question is: How did the trading sector, represented in the business activities of selected

\footnotetext{
1 Hackett Fischer, 1970: xxi.

2 See the surveys published by Van der Eng (1996) and J.Th. Lindblad (1989b, 1990, 1995a and 1995b). Extensive (statistical) information regarding the importance of trade can be found in Booth (1990, 1992 and 1998: 203-243), Van der Eng (2002a) and Lindblad (1986, 1988b, 1989a, 1994a, 1994b). The data show that exports constituted a very high percentage of national income. In 1925 exports reached 35\% of Indonesia's GDP (Booth 1990: 280, 282). Van der Eng has calculated that the total contribution of export growth to economic growth in the period 1900-1930 was more than 50\% (Van der Eng 2002a: 19).

(C) Alexander Claver, 2014.

This is an open access chapter distributed under the terms of the Creative Commons Attribution-Noncommercial-NonDerivative 3.0 Unported (CC-BY-NC-ND 3.0) License.
} 
companies, adjust to changes in its environment? Its central focus is the role of trade finance, i.e. the flow of money between the constituent parts of the trading system. Capital and credit - with regard to availability, accessibility as well as functioning - are crucial to understanding this system.

The research aims at discerning how trading companies - loosely defined as an intermediary linking buyers and sellers - functioned and the role they performed within the economic sector. Did the entrepreneurs fulfil their task by balancing a maximum of business security with a minimum of risk? Could they live up to their own and/or others' expectation by providing a profit margin sufficient for survival? Another important question concerns the identification of the participants within the trading business. Who conducted trade and how did they cooperate with each other?

Entrepreneurial activities cannot be shielded from outside influences. Identifying the possibility for independent decision-making will clarify how the trading community (i.e. traders, trading companies and banks) adapted to the challenges posed by changing circumstances. It is argued that the trader's room for manoeuvre depends upon gaining access to capital, information and security while operating on two stages within the business arena: a formal stage, based upon contractual arrangements supported by a legal framework, and an informal stage where more fluid (networks of) relationships were maintained, based upon trust and status. $^{3}$

The spatial focus of this study is on Java. Java is the fifth largest island within the Indonesian archipelago measuring $125,622 \mathrm{~km}^{2}$ with an estimated population of 136.5 million people in 2010 (see Map 1 and 2). More than half $(57.4 \%)$ of Indonesia's population of 237,6 million people lives here making it one of the most densely populated regions in the world $\left(1062 / \mathrm{km}^{2}\right) \cdot{ }^{4}$ The two largest population groups of the island are the Javanese $( \pm 85$ million $)$ in Central and East Java, and the Sundanese $( \pm 31$ million) in West Java. To the northeast of Java lies the island of Madura measuring 5,290 $\mathrm{km}^{2}$ and inhabited by 3,60o,00o people in 2010. Given Madura's poor economic resources and the island's proximity to Java over

3 Welter (2002: 37-42) emphasizes the role of institutions and environment in explaining entrepreneurship. She highlights the institutional embedding of business behaviour which includes a formal legal and political framework and 'soft' factors such as codes of conduct, norms and values.

4 The Netherlands measure $41,5^{2} 6 \mathrm{~km}^{2}$ with an estimated population in 2012 of $16,730,000$ people and a population density of $404 / \mathrm{km}^{2}$. 
6 million Madurese live in East Java (Barwegen 2005: 6-7; Cribb 2000: $2-10,33) \cdot{ }^{5} \mathrm{Java}$ is almost entirely of volcanic origin and significant parts of the island consist of deep fertile soils suitable for intensive agriculture. The wet season runs from April till July with most of the rain falling in the western part of the island (Barwegen 2005: 5-6; Cribb 2000: 11-21).

The period studied runs from 1800 till 1942. After the collapse of the VOC and arrival of the English, the nineteenth century witnessed the build-up of an economic and financial infrastructure in Java. The year 1942 saw the collapse of the colonial state and the provisional end of Dutch commercial activity with the Japanese occupation of the Netherlands Indies.

The chapters reflect developments in the (economic) history of the Indonesian archipelago. Chapter 2 gives an overview of the trading sector against the background of economic institutionalization, weak but persistent private initiative and state competition through the Cultivation System. Chapter 3 focuses on the economic crisis of 1884 and analyzes the changing relationship between capital and commerce. Chapter 4 looks at Dutch-Chinese commercial relations and discusses changing attitudes and power constellations as shown in the rise of the (Chinese) boycott. Chapter 5 highlights a period of economic progress and expanding business underpinned by speculative financial transactions and fraudulent behaviour. Chapter 6 deals with the economic crisis of the 1930s, its impact and the survival strategies of trading companies. Chapter 7 summarizes Indonesia's trading history and revisits the theme of access to capital, information and security.

\section{Access to Capital, Information and Security}

The trader's room for manoeuvre depends upon his access to capital, information, and security. Forms of socio-economic networking provide significant advantages in facilitating this (Godley 1996; Smallbone and Lyon 2002: 19-20). A trade network can be defined as the number of strategic alliances a trader makes with the purpose of exchanging material and/or immaterial goods in order to ensure a profitable result of his activities (Collins 1988: 413, 447). There are several theories with regard to entrepreneurial networks (Schijf 1993: $3-5$ ). Though different in approach these theories all acknowledge the importance of trust and status. Both

\footnotetext{
5 See also the website (www.bps.go.id) of Indonesia's government statistical office Biro Pusat Statistik (BPS Statistics Indonesia).
} 
notions - best viewed as some sort of social capital ${ }^{6}$ - serve as an illustration of the connection between economic and social activities (Menkhoff 1993).

Trust can be defined as the belief or expectation that another individual will not behave in a way that is harmful to one's interests. The importance of information and enforcement is at the core of this concept. ${ }^{7}$ Gaining access to important factors such as capital and information is in most cases achieved by obtaining other people's trust, rather than on the basis of warranties (Henley 1997). Status on the other hand is an important prerequisite in order to be deemed reliable and/or trustworthy. Though invisible, trust and status can be singled out by looking at entrepreneurial networks. ${ }^{8}$

\section{Capital}

Capital or credit can be considered the engine propelling the trading business. The banking connection is both obvious and extremely important. Banks or financial intermediaries in general respond to information. This is crucial for their functioning and also poses their biggest problem since the process of acquiring and analysing information is difficult and costly. Informal, qualitative and case-specific information is very hard to come by and often impossible to trade. Gaining access to this kind of data however gives the mediator a distinct advantage when performing his task. (Godley and Ross 1996:3).

The credit market is characterised by incomplete contracts. The interest a borrower agrees to pay is the price he promises to pay the lender over a period of time (Godley and Ross 1996: 2). Interest payments constitute the price tag attached to credit. The lender will only settle for this promise with the assurance of sufficient collateral. However, in order to form judgement he has to rely on specific information concerning the proposed venture. In most instance, such information can only be obtained from the borrower himself.

6 See www.socialcapitalgateway.org for a useful overview of the debate on social capital.

7 Guinnane (2005: 1, 29-31) warns that the concept of trust has been used so loosely that it tends to create confusion. He argues that in economic research useful parts of the idea of trust are implicit in notions of information and the ability to impose sanctions. In other words: "I trust you in a transaction because of what I know about you, and because of what I can have done to you should you cheat me."

8 The amount of literature on the concepts of trust, status and networks is overwhelming. The following books and articles look at this subject matter from a business point of view: Barton (1983), Casson (1995), Gambetta (1988), Menkhoff (1993), Smets (1999). 
In the case of the Netherlands Indies in the nineteenth century the risks of the credit business were increased by the difficulty of obtaining security. Mortgages could not be obtained on leased lands no matter if these contracts had expiration dates of 99 years. In addition, only factory inventory could be mortgaged since this represented a retrievable capital investment (Allen and Donnithorne 1957: 186). Operating in this market called for specialised intermediaries able to assess the amount of credit to be extended. Bankers and traders thus had to develop methods to deal with asymmetric information since only the loan applicant knew the kind of details needed for a sound judgement of the request.

\section{Information}

All enterprises collect commercial information, but in the case of trading companies acquiring information lies at the heart of their activities. ${ }^{9}$ Knowledge can be considered their prime asset since they do not produce physical goods. The emphasis on information instead of production helps to explain why trading enterprises are considered elusive. The conventional view of the economy is one of a system of material flow focused on the handling of physical commodities (Casson 1997: 153, 163).

Trading enterprises depend heavily on their position within wider commercial networks as these constitute their source base. This explains why traders are usually more interested in access than control. Access enables them to exert control. Commercial networks also comprise political and social elements. The successful combination of all these elements optimizes opportunities. Here, notions like personal integrity, reputation and trust surface. Ultimately, the successful functioning of a network rests on high levels of trust which are facilitated by ethnic, cultural and social background (Jones 1998: 19).

A trader handles flows of material goods on the basis of information. Much of this information is part of a routine procedure repeated at every transaction, mainly involving elements of procurement and distribution. Customer orders have to be processed, payments have to be recorded, goods have to be bought from suppliers and outstanding debts or credits filed. Though important this is not the most interesting information for the trader. Above all he has to ascertain how much his services in

9 The retrieval of information for business purposes is considered an important management tool nowadays. This has been formalized in the concept of business intelligence (Rodenberg 1999: 35, 79-81, 157). 
handling certain products are in demand and when buying/reselling products he needs to speculate or hedge against price movements during the time they are in his possession.

All this information is difficult to come by and he will have to rely on a network of contacts feeding him relevant information, ranging from confidences and gossip to newspapers and magazines (Casson 1998: $35^{-36}$ ). The importance of the latter can, for example, be seen from the list of subscriptions to newspapers and journals the chambers of commerce and trading associations in Batavia, Semarang and Surabaya published in their annual reports.

\section{Security}

There are different ways to achieve security against competitors, breach of contract, unexpected price movements, harbour strikes, etc. First, there is the possibility of institutionalised security. Insurance is an important feature in this respect and the Netherlands Indies offered attractive opportunities as many insurance companies were active, especially in Java. There was also the possibility of resorting to the legal system, which however in the colonial setting often did not live up to the traders' expectations.

Second, there is the possibility of establishing co-operative bodies. Industry and trade organisations can be particularly effective in defending the collective interest against the 'hostile' outside world. One of the ways to achieve this is by active participation in this 'hostile' world. This could be done by taking up seats in local, regulating bodies - like town councils - or advisory boards. In other cases a code of practice was established (Casson 1997: 162-163). The sugar trade in Java can serve as an example of this type of security seeking since the sector successfully organised its collective interest into co-operative bodies ([Javasuiker] 1932/1933; Allen and Donnithorne 1957: 84-85).

Mediation constitutes a core element in the trading process. In theory, other players in the economic process, such as producers and governments, can take over (parts of) this process. Despite this constant threat the trading enterprise has never been outmanoeuvred. It appears to perform a function that can only be acquired at great cost. Most authors tend to locate this specific quality in the acquisition of (relevant) knowledge. The notion of access offers good opportunities in clarifying this process by showing how traders fight their battles with regard to the procurement of capital, information and security. 


\section{The Indonesian Case}

Some features of trade require attention. First, there is the distinction between import and export. The trading company can focus on both aspects, or limit itself to one of the two. The well-known Dutch company Internatio did both, but the German company Erdmann and Sielcken concentrated itself on exports, primarily sugar ([Internatio] 1913; [Internatio] 1938; Schmiedell 1924). In the colonial trade general trading companies and specialized ones existed side by side. ${ }^{10}$ The large successful general trading company has received most of the attention, although most trading outfits were small and focused on a limited range of products.

Second, there is the difference between wholesale and retail trade. Most European traders in the Netherlands Indies were wholesale traders. Neither willing nor able to compete in the local intermediate trade, European traders provided middlemen with merchandise on credit in the expectation that their products would thus reach the consumer market.11 The intermediate trade was traditionally the domain of the Chinese, although Arab and Japanese merchants participated as well. ${ }^{12}$ Chinese predominance owed much to their cultural background and ethnic minority position which seems to have favoured the development of certain business skills, as well as their extensive family and business contacts which gave them unrivalled access to intra- and extra-archipelago trade networks. ${ }^{13}$

Third, in the case of imports intermediate trade was tantamount to distributive trade or the so-called second hand (tweede hand). ${ }^{14}$ There

10 A general trading company is defined here as a firm active in both import and export that will trade all kinds of goods all over the world. See Yonekawa and Yoshihara (1987) and Yonekawa (1990).

11 This had been the case from the earliest days of the VOC. Being a wholesale organization the Company could not afford to be bothered by small sales on the local market. As stated by the Governor General in 1639 the objective was not to enter the intermediate market and open the warehouses for a mere trifle at the demand of every prospective customer (Blussé 1986: 71).

12 A description of the economic position of the Arab community in general and Arab trading activities in particular can be found in Heuken (1996), De Jonge (2000:145-146) and Mandal (1994: 39-52). Post (1991) provides an in-depth analysis of the Japanese trade.

13 See Chapter 4, Paragraph 'An Awkward Alliance: the Interdependence of Dutch and Chinese Business'.

14 This concept has been formalized by T.P. van der Kooy in his Hollands stapelmarkt en haar verval. His argumentation highlights the crucial importance of 'the second hand' during the Dutch Republic (sixteenth and seventeenth century). These traders acted as a 'buffer' between irregular supplies and more regular sales. In his opinion, it was their knowledge of local market conditions - i.e. better access to information - which made them invaluable intermediaries. Van der Kooy also mentioned the speculative function 
was also often a third, fourth or even fifth hand (Liem Twan Djie 1947: $4-11) \cdot 15$

The distribution chain typically went from European importer to Chinese middlemen. The latter could be highly specialized, but the pasar enterprise - which sold just about anything - was equally important. From the intermediate trader the goods were distributed further down the chain. The merchandise was sold in shops: toko, or in even smaller warung in the villages (desa). Goods were also traded by small peddlers who would sell the merchandise in every conceivable spot. The Chinese (Cina klontong) with his carrying pole (pikulan) was a common sight everywhere. Last but not least, there was the market (pasar) in which Chinese and indigenous traders were active.

In the case of exports intermediate trade meant collecting the merchandise. Petty traders would buy small quantities of local agricultural and industrial produce. These would be bundled and sold to retail traders. The retail traders could however also decide to buy directly from local producers. Wholesale traders would buy goods from retailers or directly from factories in the case of processed agricultural products like sugar.

Fourth, the import and export trade of the Netherlands Indies thrived on credit. It acted as a lubricant for the trading sector and the entire economy. Access to sufficient capital was a precondition for the smooth running of the economic system. Credit was hard to come by and securing it was easier for those with access to socio-economic networks. From the top of the pyramid capital trickled down to those involved in trade, production, or consumption.

Substantial risks were attached to the extension of credit. As late as 1924 E.G.J. Gimbrère ${ }^{16}$ pleaded for a clearly defined use of terminology and standardization of contracts (Gimbrère 1924: v-viii, 3-7). According to him trade boiled down to the creditworthiness of the participants. This

this type of trader fulfilled by pointing out the extremely small profit margins he had to accept (Van der Kooy 1931: 21-22, 45, 85-89).

15 A good illustration of this system is the distribution of opium on the black market as described by Rush. This so-called patungan trade system had a pyramidal structure and was carried out below the level of the state sanctioned opium farm stores by numerous street hawkers (Rush 1990: 57-63).

16 E.G.J. Gimbrère (1891-1949) practised law in Padang before he was employed by the Nederlandsch-Indische Handelsbank (NIHB) in 1917. He became Director in Batavia in 1926, but returned to the Netherlands in 1927 to take up a position as professor of law at the university of Tilburg. Throughout his (academic) career he published extensively on topics such as credit practices in trade and sugar finance (Korthals Altes 2004: 247, 282, 527; Gimbrère 1924 and 1928). 
meant assessing the extent to which risks could be covered. Sufficient collateral was a key condition since borrowing took place on security. This was greatly aided by clear liabilities. Still, as will be shown, being able to hold someone liable does not guarantee a favourable outcome when debtors default on their payments.

\section{Sources}

In Indonesia consultation of the archive of De Javasche Bank (DJB) at Bank Indonesia (BI), Jakarta provided unique material. Material was also found in Arsip Nasional in Jakarta and the private archive of coffee factory Margo-Redjo in Semarang. In the Netherlands the Nationaal Archief in Den Haag was of great importance, especially the archives of the Nederlandsche Handel-Maatschappij (NHM), the Koloniale Bank (KB), the Handelsvereeniging Amsterdam (HVA), and the Ministerie van Koloniën. Other archives worth mentioning are Internatio-Müller in Rotterdam, the Koninklijk Instituut voor Taal-, Land- en Volkenkunde in Leiden and the Nederlandsch Economisch-Historisch Archief in Amsterdam.

Newspapers, magazines and other serial publications were crucial in supplementing and/or cross-checking data. Issues of Soerabaiasch Handelsblad, De Locomotief, or De Indische Mercuur were particularly useful in giving a more complete picture of specific events. In addition differences in point of view of these and other publications like Kabar Perniagaan, Pembrita Betawi, or De Telefoon shed more light on divisions within colonial society. ${ }^{17}$ Serial publications like the year reports of trading companies and societies contained invaluable statistical data.

The interviews conducted provided the kind of unique background and atmospheric impressions hardly ever found on paper, save for the few well-written works of fiction. ${ }^{18}$ Extensive library research was conducted in general and specialized libraries. ${ }^{19}$

17 For more information on the press in the Netherlands Indies see Adam (1995), Bosma, Sens and Termorshuizen (2005), Hoogerwerf (1990), Maters (1998) and Termorshuizen (2001, 2011).

18 The interviews conducted with F.L.N. van de Ven (Pak Ferry), Pak Joenoes, and members of the Tan/Dharmowiyono family were of great importance in this respect. See Beekman (1996 and 1998), Birney (1998) and Nieuwenhuys (1972) for an overview of fiction dealing with the Netherlands Indies.

19 In the Netherlands: the Vrije Universiteit Amsterdam, the Universiteit van Amsterdam, the Koninklijke Bibliotheek in Den Haag, the Universiteit van Leiden, the Koninklijk Instituut voor Taal-, Land- en Volkenkunde in Leiden, the Koninklijk Instituut voor de Tropen in Amsterdam, the Erasmus Universiteit Rotterdam, and the Institute of 


\section{Research Method}

The following pages reflect a historian's exercise. Practical use has been made of economic science concepts to strengthen the argument and shed light on long-term historical developments. The study is archive-driven since it is primarily based upon archival sources: many of them new and/ or neglected by other scholars (Ankersmit 1986: 233-247; Breisach 1983: 291-302, 337-341, 355-360; Aslanian 2011: xv-Xviii).

Chronology and case studies constitute important elements in the narrative below. The word narrative stands for the organization of historical knowledge into an explanatory scheme which takes the form of a coherent story. ${ }^{20}$ Cases form an integral part of this story as they relate to the type of phenomena of the research. ${ }^{21}$

The argument alternates between the macro and micro level, between broader political and economic issues and the decisions made by companies and individuals. The selected case studies focus on Java and the trading world of Batavia, Semarang and Surabaya since a significant part of the 'commercial action' in Java took place in these urban surroundings. This spatial setting is complemented by a sectoral focus on wholesale and intermediate trade emphasizing the commercial relations between Europeans and Chinese.

The research does not seek a macro-level explanation, but offers a detailed examination of the wholesale trading arena and selected

Social Studies in Den Haag. In Indonesia: the Perpustakaan Nasional in Jakarta, the Centre for Strategic and International Studies in Jakarta, the Koleksi George Hicks at the Lembaga Ilmu Pengetahuan Indonesia in Jakarta, and the Perpustakaan Mangkunegara in Surakarta.

20 The word explanation should be used with caution. A historical narrative is not an image or an explanation of the past, but an interpretation at best. A historian provides an interpretation of the past by showing cohesion into something which appeared incoherent or without structure. Historical knowledge has been characterized as the arrangement of knowledge since it neither produces theory nor tests theory against the facts (Ankersmit 1983: 250; Ankersmit 1986: 182-190). Narration is one of the more common forms historians use to that effect. See Ankersmit (1986) and Lorenz (1987) for an overview of explanatory paradigms used in historical science.

21 The use of cases is a well-established method in social science research where controlled experiments are hardly feasible. The choice of a case study involves greater detail and accuracy of information at the cost of making less effective generalizations. The selection of a representative case is therefore crucial. The selection process involves hard to define concepts such as relevancy and significance. Hammersley (1993: Chapter 10-11) surveys case studies and alternative research strategies. Lustick (1996) deals with selection bias and argues for greater historiographical consideration to help focus investigation and explanation. 
companies. This avoids making unexamined assumptions like the wellestablished perception of total Dutch dominance of wholesale business in Java. The resulting increase in complexity is balanced by a better understanding of historical developments offering a more solid basis for future research (Van Klinken 2005: 79-81). 